\title{
Phenytoin-induced gingival enlargement
}

\author{
Lisa Neelathil Chacko, ${ }^{1}$ Sathish Abraham²
}

${ }^{1}$ Department of

Periodontology, S.M.B.T. Dental College \& Hospital, Sangamner, Maharashtra, India ${ }^{2}$ Department of Conservative Dentistry and Endodontics, S.M.B.T. Dental College \& Hospital, Sangamner, Maharashtra, India

\section{Correspondence to} Dr Sathish Abraham, abrahamsathish@yahoo.in

Accepted 5 May 2014

\section{DESCRIPTION}

Gingival overgrowth occurs as a side effect of some systemic medications. It is now well established that phenytoin is one such agent. It has multiple therapeutic indications ranging from convulsive disorders and neuralgias to cardiac arrhythmia. The incidence rate of phenytoin-induced gingival overgrowth ranges from $3 \%$ to $93 \%$, but $50 \%$ of patients on long-term therapy are prone to develop gingival overgrowth. This drug-induced overgrowth is noticed initially in the papillary region and during the course of the process involves the margins and the gingival attachment. As the tissue enlarges, it develops a characteristically lobulated and thickened appearance either partially or sometimes completely covering the tooth surfaces. The colour ranges from pink to a deep bluish red depending on the amount of inflammatory infiltrate present in the tissues and secondary inflammation may induce oedema, ulcerations and bleeding. The overgrowth takes $2-3$ months to become noticeable and can take $12-18$ months to reach its maximal severity. The anterior teeth are more commonly involved when compared to posterior teeth with greater involvement seen on the buccal surface. Some concerns experienced by the patient include unsightly appearance, discomfort, interference with mastication and speech, impediment of oral hygiene activities resulting in halitosis and in severe extents even normal alignment of the teeth is altered. $^{1}$

The pathogenesis of phenytoin-induced gingival overgrowth is multifactorial. The fundamental disturbance occurs in the gingival fibroblast. The inflammatory changes that occur within the gingival tissues seem to orchestrate the interaction between the drug and fibroblast. Phenytoin and its metabolites have a direct action on the highactivity fibroblast population present in the gingiva leading to a subsequent increase in collagen production. The gingival fibroblasts can also metabolise phenytoin and this may determine the susceptibility of the patient to phenytoin-induced gingival enlargement. A positive relationship exists between the dose of phenytoin and severity of the overgrowth. Some unwanted effects of phenytoin that may relate to gingival overgrowth are immunosuppression, folic acid depletion, suppression of adrenocortical and changes in calcium metabolism. ${ }^{2}$

Identification of patients at risk is crucial to adopt measures to minimise the onset and severity of this condition. Medical practitioners should ideally inform patients of the possibility of this adverse effect of the drug and emphasise the importance of a dental check up at least twice in the first 3 months after phenytoin therapy is initiated. Dental professionals can motivate affected individuals to maintain better oral hygiene practices which can diminish the side effects and even reduce the likelihood of surgical intervention. Reducing the dose or providing suitable drug substitution often brings about partial or complete regression of the lesion and can be considered after a physician consult. However, in severe enlargements surgical gingival resection would be required. Scalpel gingivectomy, flap surgery, electrosurgery and laser gingivectomy are the surgical modalities frequently used to manage severe overgrowths. $^{3}$ Thus good communication and
To cite: Chacko $L N$, Abraham S. BMJ Case Rep Published online: [please include Day Month Year] doi:10.1136/bcr-2014204670

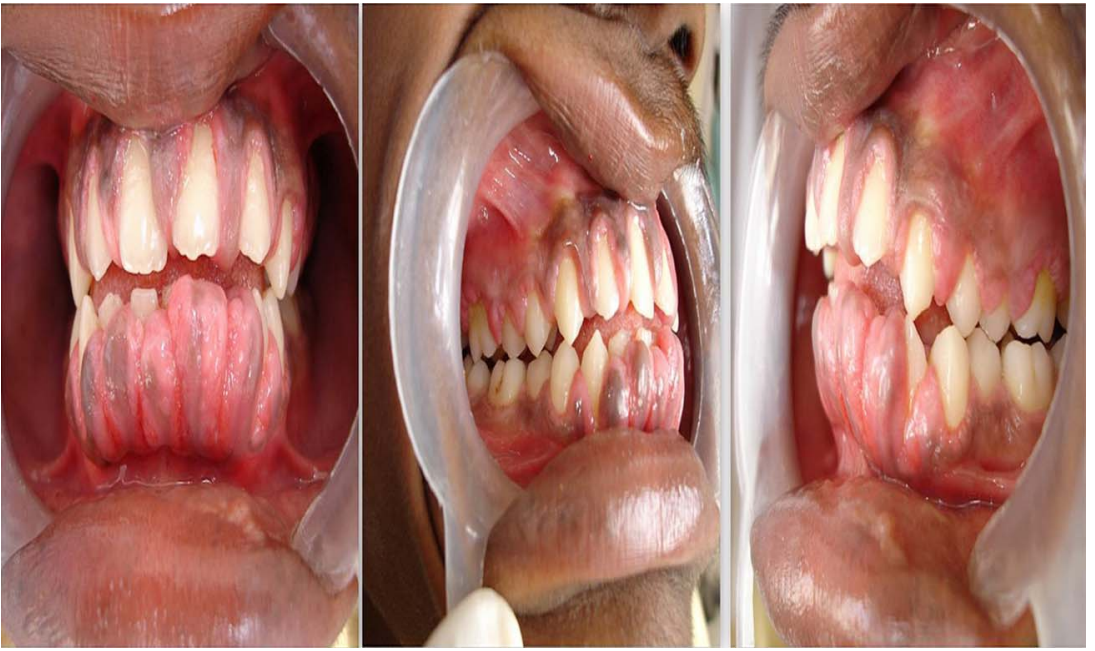

Figure 1 Preoperative photographs. 
Figure 2 Gingivectomy.

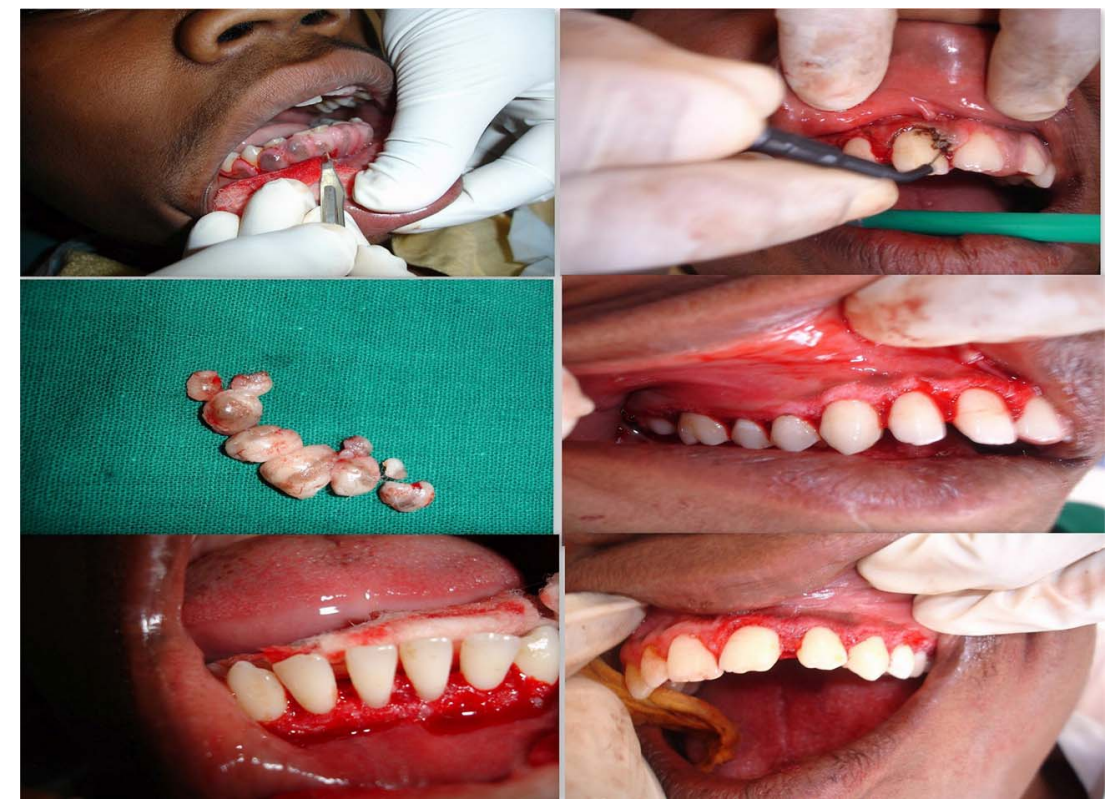

cooperative team work among patient, physician and dentist is needed to manage drug-induced gingival overgrowths.

One such case of phenytoin-induced gingival enlargement (figure 1) was treated with different strategies. Conventional intervention by scalpel technique was attempted for massive overgrowth with mandibular arch as it would take less chair time and less patient discomfort. However, the area bled profusely and hence the maxillary arch overgrowth was eliminated by an electrosurgical method which involved controlled tissue haemorrhage and better patient acceptability. ${ }^{3}$ Healing was uneventful with both methods used. Loss of pigmentation could be attributed to gingivoplasty (reshaping after excision of gingiva) method which involved the use of a Kirkland knife to scrape the raw connective tissue bed for a festooned appearance of gingiva. Surgical depigmentation was not a conscious attempt in this case; the major concern was eliminating the overgrowth. Studies have shown that repigmentation could occur from over a month to 7 years later. ${ }^{4}$
However, figures 2 and 3 show the treatment rendered (gingivectomy) and systematic follow-up (2 weeks, 3 months, 6 months and 24 months).

\section{Learning points}

- Medical practitioners should explain the possibility of gingival overgrowth as an adverse effect of phenytoin therapy to their patients.

- Dental referral of affected patients would ensure they are motivated to keep meticulous oral hygiene.

- Severe overgrowths can be managed by gingival resection techniques (surgical, electrosection and laser).

- Drug substitution can be considered after consulting the physician if the overgrowth recurs.
Figure 3 Postoperative photographs (2 weeks, 3 months, 6 months and 24 months).

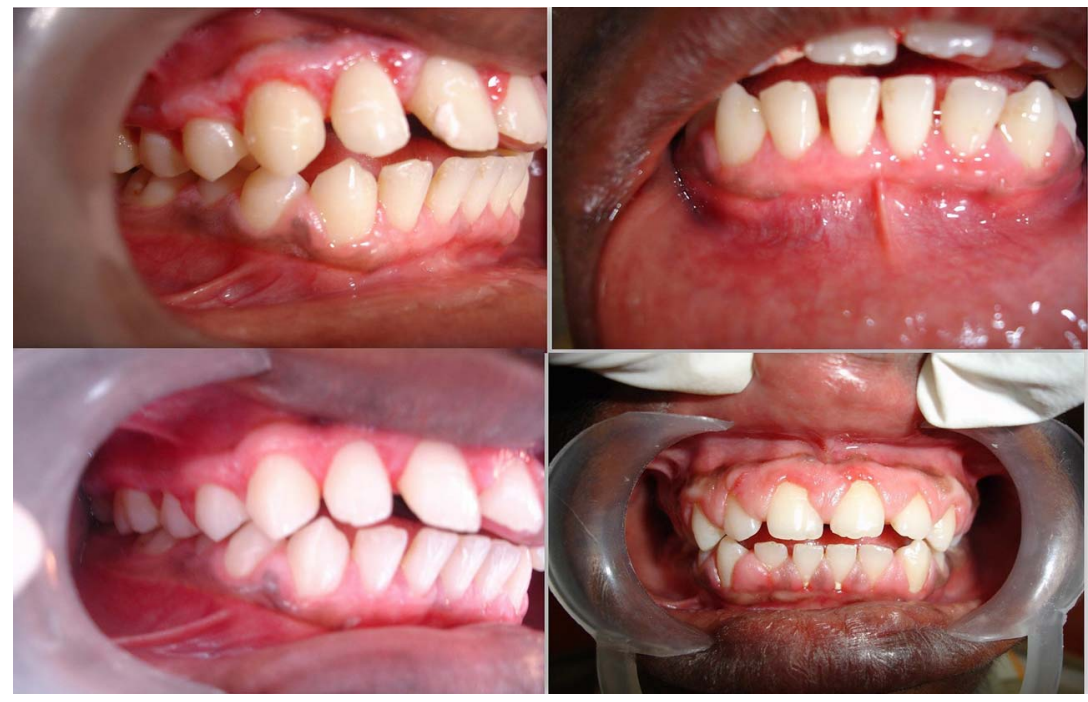


Competing interests None.

Patient consent Obtained.

Provenance and peer review Not commissioned; externally peer reviewed.

\section{REFERENCES}

1 Bharti V, Bansal C. Drug-induced gingival overgrowth: the nemesis of gingiva unravelled. J Indian Soc Periodontol 2013;17:182-7.
2 Corrêa JD, Queiroz-Junior CM, Costa JE, et al. Phenytoin-induced gingival overgrowth: a review of the molecular, immune and inflammatory features. ISRN Dent 2011;2011:497850.

3 Shiva Shankar B, Ramadevi T, Neetha MS, et al. Chronic inflammatory gingival overgrowths: laser gingivectomy and gingivoplasty. J Int Oral Health 2013;5: 83-7.

4 Mahesh HV, Harish MR, Shashikumar BM, et al. Gingival pigmentation reduction: a novel therapeutic modality. J Cutan Aesthet Surg 2012;5:137-40.

Copyright 2014 BMJ Publishing Group. All rights reserved. For permission to reuse any of this content visit http://group.bmj.com/group/rights-licensing/permissions.

BMJ Case Report Fellows may re-use this article for personal use and teaching without any further permission.

Become a Fellow of BMJ Case Reports today and you can:

- Submit as many cases as you like

- Enjoy fast sympathetic peer review and rapid publication of accepted articles

- Access all the published articles

- Re-use any of the published material for personal use and teaching without further permission

For information on Institutional Fellowships contact consortiasales@bmjgroup.com

Visit casereports.bmj.com for more articles like this and to become a Fellow 